\title{
Export Competitiveness of Dry Onion with Reference to India
}

\section{Sonali Katoch" and Rakesh Singh}

Department of Agricultural Economics, Institute of Agricultural Sciences, Banaras Hindu University, Varanasi, India

"Corresponding author: katoch.sonali@gmail.com (ORCID ID: 0000-0003-0739-4260)

Received: $19-09-2021$

Revised: $30-11-2021$

Accepted: $10-12-2021$

\begin{abstract}
The purpose of the study is to examine the export competitiveness of onion with reference to India. In India, exports are allowed only after domestic requirements are met, due to which there arise year-to-year export fluctuations. Revealed Comparative Advantage Index (RCA) and Comparative Export Performance Index (CEP) are used to examine export competitiveness. The study reveals that India has comparative advantage in export of onion as compared to other major exporting nations followed by The Netherlands and Egypt. The performance index of India shows rise of Indian onion in world market, as the value of CEP index is decreasing for other exporting nations.

HIGHLIGHTS

( The RCA index indicates that Indian onion holds a potential position in international trade.

0 The CEP index indicates rise of Indian onion export compared to other nations (for period: 2008-2019).
\end{abstract}

Keywords: Comparative advantage, competitiveness, Balassa index, export performance

India has come a long way from the nation often treated as a traditional grower to one of the main exporters in agriculture and allied sectors. In India, onion is one of the major commodities when it comes to trade in the international market, and the dynamics of the crop can even bring down the governments. In recent years, there has been a high commodity concentration of agricultural trade because of a global shift in consumer preferences toward high-value food products (Varma and Issar, 2016). This shift has lead India in the path of major onion export nations. India has exported 1149896.85 MT of fresh onion for ₹ 2320.70 crores during the year 2019-20 (APEDA, 2021). The major importing countries of the Indian onion are Bangladesh, Malaysia, UAE, Sri Lanka, and Nepal, which may be because of a preference for strong pungency.

The increased international trade opportunities and the competitiveness of agricultural commodities have become an important dimension. Indian Onion export has seen many ups and down either due to price and production fluctuations, or sometimes due to ban imposed by exporting nations (Bendre and Newaskar, 2014). Competitiveness is the ability of a country to produce and distribute products that can compete globally and increase the real income of the producers (Kumar and Gummagolmath, 2021). Thus, a deeper understanding of the dynamics of trade performance would contribute towards strategy development. In view of this, the study is attempted with the objectives to assess the export competitiveness of onion crop with respect to quantity and value exported.

\section{METHODOLOGY}

\section{Data Collection}

The secondary data is employed to accomplish the objectives of the study. The information regarding major export destinations of Indian onion from

How to cite this article: Katoch, S. and Singh, R. (2021). Export Competitiveness of Dry Onion with Reference to India. Economic Affairs, 66(04): 629-633.

Source of Support: None; Conflict of Interest: None (a) 9 
2008-2019 is obtained from the Agricultural and Processed Food Products Export Development Authority (APEDA). The export quantity and value data to examine the export competitiveness of India and other major exporting countries are culled from Food and Agriculture Organization (FAO).

\section{Export Competitiveness}

Revealed Comparative Advantage Index (RCA) and Comparative Export Performance Index (CEP) are used to examine export competitiveness (Balassa, 1965). These indices provide more precise information about the ability of a country to survive and gain large market shares relative to other countries.

\section{Revealed Comparative Advantage Index}

RCA Index is defined as a country's share of world exports of a commodity divided by its share of total world exports. It uses a relative share of the individual country to examine whether the country has a comparative advantage or disadvantage over the rival countries.

$$
R C A_{i j} \frac{\left(j{ }^{i j} /{ }_{i t}\right)}{\left(w j /{ }_{w t}\right)}
$$

Where, $X_{i j}=$ value of country $i$ export of product $j$ (onion)

$X_{i t}=$ value of country $i$ total export (fruit and vegetables)

$X_{w i}=$ values of countries total onion export

$X_{w t}=$ values of world's total export (fruits and vegetables)

The calculated value of the index lies between zero to infinity. If the value of the index is greater than one, then it shows that country has revealed comparative advantage in onion and the value less than one indicates the country's comparative disadvantage.

However, RCA suffers from the problem of asymmetry as pure RCA is basically not comparable on both sides of unity. The index is made symmetric, following the methodology suggested by Dalum, Laursen and Villumsen (1998), Widodo (2009), and Laursen (2015) called Revealed Symmetric Comparative Advantage (RSCA).

A modified formula is;

$$
R S C A=\frac{(R C A-1)}{(R C A+1)}
$$

The value of RSCA ranges between -1 to +1 and is free from the problem of skewness. A commodity is said to have comparative advantage in its exports if the corresponding RSCA value is positive and disadvantage if the corresponding RSCA value is negative (Shinoj and Mathur, 2008).

\section{Comparative Export Performance Index}

CEP index measures the strength of the competition, calculated by dividing a country's share in the exports of a commodity by the share in the world exports. CEP index of major producing countries is analysed and compared with India's CEP index. The index number getting better for a commodity of a country indicates a comparative advantage (Rao and Ankalam, 2018). The index for country i, commodity $j$ is calculated as;

$$
C E P=\frac{\left(X_{i j} / X_{i}\right)}{\left(X_{a j} / X_{a}\right)}
$$

Where, $X_{i j}=$ Export of product $j$ from country $i$

$X_{i}=$ Total exports from country $i$

$X_{a j}=$ Total export of product $j$ from the world

$X_{a}=$ Total exports from the world

If the value of the CEP index is greater than one, a country has a competitive advantage against other country.

CEP also suffers from the problem of asymmetry. The index is made symmetrical by Symmetric Comparative Export Performance Index (SCEP).

$$
S C E P=\frac{(C E P-1)}{(C E P+1)}
$$

SCEP is perceived to provide the best picture on performance of a country by setting boundaries between -1 and +1 . The closer a given country to +1 , the higher its export performance and vice versa. 


\section{RESULTS AND DISCUSSION}

\section{Export Competitiveness}

\section{Revealed Comparative Advantage Index (RCA)}

The RCA is derived from the export of onion of the selected countries to the world during the period 2008-2019. A perusal of the table 1 reveals that the quantity and value index of The Netherlands, India, and Egypt is greater than one for selected period (2008-19), and Pakistan has RCA $>1$ for every alternate couple of years. The results indicate that these countries have a comparative advantage in onion export from rest of the world. The RCA index of India is greater than other countries, which means India holds an upper hand in onion export and Indian onion has its own demand and position in international market.

\section{Revealed Symmetric Comparative Advantage (RSCA)}

The calculated RCA is further redefined as RSCA which ranges from -1 to +1 . A perusal of the table 2 reveals that values of the index for 'quantity' as well as 'value' are closer to +1 for India followed by Egypt, meaning these countries have a better position in onion export.

Table 1: Revealed Comparative Advantage Index of onion export quantity and value from 2008-19

\begin{tabular}{|c|c|c|c|c|c|c|c|c|c|c|c|c|}
\hline \multicolumn{13}{|c|}{ QUANTITY } \\
\hline & 2008 & 2009 & 2010 & 2011 & 2012 & 2013 & 2014 & 2015 & 2016 & 2017 & 2018 & 2019 \\
\hline China & 0.48 & 0.46 & 0.52 & 0.59 & 0.53 & 0.62 & 0.65 & 0.78 & 0.58 & 0.74 & 0.72 & 0.70 \\
\hline Netherlands & 1.30 & 1.40 & 1.33 & 1.44 & 1.45 & 1.41 & 1.51 & 1.51 & 1.40 & 1.53 & 1.44 & 1.36 \\
\hline India & 5.87 & 6.06 & 5.06 & 4.17 & 5.56 & 4.93 & 4.61 & 4.74 & 5.77 & 5.79 & 5.84 & 4.63 \\
\hline USA & 0.39 & 0.36 & 0.42 & 0.40 & 0.40 & 0.40 & 0.39 & 0.38 & 0.38 & 0.40 & 0.46 & 0.48 \\
\hline Egypt & 1.09 & 1.52 & 2.83 & 2.27 & 2.34 & 1.63 & 1.89 & 2.70 & 1.92 & 1.99 & 1.17 & 1.26 \\
\hline China & 0.38 & 0.42 & 0.43 & 0.50 & 0.60 & 0.57 & 0.70 & 0.72 & 0.67 & 0.79 & 0.75 & 0.74 \\
\hline Netherlands & 0.92 & 0.95 & 1.21 & 1.12 & 1.08 & 1.06 & 1.12 & 0.96 & 1.09 & 1.03 & 1.15 & 1.19 \\
\hline India & 7.11 & 7.60 & 5.73 & 4.07 & 4.07 & 5.51 & 3.76 & 4.70 & 4.27 & 4.77 & 4.84 & 3.65 \\
\hline USA & 0.47 & 0.41 & 0.47 & 0.40 & 0.45 & 0.39 & 0.43 & 0.35 & 0.41 & 0.40 & 0.41 & 0.44 \\
\hline
\end{tabular}

Source: Author's own Calculations.

Table 2: Revealed Symmetric Comparative Advantage Index of onion export quantity and value from 2008-19

\begin{tabular}{|c|c|c|c|c|c|c|c|c|c|c|c|c|}
\hline \multicolumn{13}{|c|}{ QUANTITY } \\
\hline & 2008 & 2009 & 2010 & 2011 & 2012 & 2013 & 2014 & 2015 & 2016 & 2017 & 2018 & 2019 \\
\hline China & -0.35 & -0.37 & -0.32 & -0.26 & -0.30 & -0.24 & -0.21 & -0.12 & -0.27 & -0.15 & -0.16 & -0.18 \\
\hline Netherlands & 0.13 & 0.17 & 0.14 & 0.18 & 0.18 & 0.17 & 0.20 & 0.20 & 0.16 & 0.21 & 0.18 & 0.15 \\
\hline India & 0.71 & 0.72 & 0.67 & 0.61 & 0.69 & 0.66 & 0.64 & 0.65 & 0.70 & 0.71 & 0.71 & 0.64 \\
\hline USA & -0.44 & -0.47 & -0.41 & -0.42 & -0.43 & -0.43 & -0.44 & -0.44 & -0.45 & -0.43 & -0.37 & -0.36 \\
\hline Egypt & 0.04 & 0.21 & 0.48 & 0.39 & 0.40 & 0.24 & 0.31 & 0.46 & 0.32 & 0.33 & 0.08 & 0.12 \\
\hline Pakistan & -0.13 & -0.29 & 0.17 & 0.23 & -0.42 & -0.02 & 0.17 & 0.35 & -0.06 & -0.11 & 0.32 & 0.19 \\
\hline \multicolumn{13}{|c|}{ VALUE } \\
\hline China & -0.45 & -0.41 & -0.40 & -0.33 & -0.25 & -0.27 & -0.18 & -0.16 & -0.19 & -0.12 & -0.15 & -0.15 \\
\hline Netherlands & -0.04 & -0.03 & 0.09 & 0.06 & 0.04 & 0.03 & 0.06 & -0.02 & 0.04 & 0.01 & 0.07 & 0.09 \\
\hline India & 0.75 & 0.77 & 0.70 & 0.61 & 0.61 & 0.69 & 0.58 & 0.65 & 0.62 & 0.65 & 0.66 & 0.57 \\
\hline USA & -0.36 & -0.42 & -0.36 & -0.43 & -0.38 & -0.44 & -0.40 & -0.48 & -0.42 & -0.42 & -0.42 & -0.39 \\
\hline Egypt & 0.23 & 0.51 & 0.57 & 0.55 & 0.54 & 0.48 & 0.49 & 0.61 & 0.53 & 0.52 & 0.25 & 0.48 \\
\hline Pakistan & 0.13 & -0.13 & 0.30 & 0.39 & -0.28 & 0.04 & 0.20 & 0.35 & -0.13 & -0.07 & 0.46 & 0.54 \\
\hline
\end{tabular}

Source: Author's own Calculations. 
Table 3: Comparative Export Performance Index of onion export quantity and value for period 2008-19

\begin{tabular}{|c|c|c|c|c|c|c|c|c|c|c|c|c|}
\hline \multicolumn{13}{|c|}{ QUANTITY } \\
\hline & 2008 & 2009 & 2010 & 2011 & 2012 & 2013 & 2014 & 2015 & 2016 & 2017 & 2018 & 2019 \\
\hline China & 12.20 & 13.31 & 9.75 & 7.08 & 10.43 & 8.00 & 7.09 & 6.05 & 9.97 & 7.82 & 8.11 & 6.60 \\
\hline Netherlands & 4.52 & 4.34 & 3.80 & 2.90 & 3.84 & 3.49 & 3.06 & 3.14 & 4.14 & 3.79 & 4.07 & 3.41 \\
\hline USA & 15.04 & 16.62 & 12.16 & 10.30 & 14.02 & 12.35 & 11.72 & 12.33 & 15.24 & 14.43 & 12.68 & 9.72 \\
\hline Egypt & 5.40 & 4.00 & 1.79 & 1.84 & 2.38 & 3.03 & 2.44 & 1.76 & 3.00 & 2.91 & 4.98 & 3.66 \\
\hline Pakistan & 7.68 & 11.04 & 3.61 & 2.63 & 13.52 & 5.09 & 3.26 & 2.30 & 6.52 & 7.27 & 2.99 & 3.12 \\
\hline \multicolumn{13}{|c|}{ VALUE } \\
\hline China & 18.55 & 18.32 & 13.23 & 8.07 & 6.80 & 9.66 & 5.36 & 6.51 & 6.34 & 6.06 & 6.48 & 4.95 \\
\hline Netherlands & 7.73 & 8.04 & 4.74 & 3.63 & 3.76 & 5.21 & 3.35 & 4.88 & 3.92 & 4.64 & 4.20 & 3.07 \\
\hline USA & 15.24 & 18.75 & 12.26 & 10.19 & 8.97 & 14.16 & 8.78 & 13.35 & 10.44 & 11.80 & 11.82 & 8.37 \\
\hline Egypt & 4.43 & 2.45 & 1.56 & 1.17 & 1.22 & 1.92 & 1.28 & 1.12 & 1.30 & 1.51 & 2.89 & 1.28 \\
\hline Pakistan & 5.45 & 9.80 & 3.06 & 1.80 & 7.28 & 5.14 & 2.51 & 2.27 & 5.51 & 5.53 & 1.78 & 1.08 \\
\hline
\end{tabular}

Source: Author's own Calculations.

Table 4: Symmetric Comparative Export Performance Index of onion export quantity and value for period 2008-19

\begin{tabular}{|c|c|c|c|c|c|c|c|c|c|c|c|c|}
\hline \multicolumn{13}{|c|}{ QUANTITY } \\
\hline & 2008 & 2009 & 2010 & 2011 & 2012 & 2013 & 2014 & 2015 & 2016 & 2017 & 2018 & 2019 \\
\hline China & 0.85 & 0.86 & 0.81 & 0.75 & 0.83 & 0.78 & 0.75 & 0.72 & 0.82 & 0.77 & 0.78 & 0.74 \\
\hline Netherlands & 0.64 & 0.63 & 0.58 & 0.49 & 0.59 & 0.55 & 0.51 & 0.52 & 0.61 & 0.58 & 0.61 & 0.55 \\
\hline USA & 0.88 & 0.89 & 0.85 & 0.82 & 0.87 & 0.85 & 0.84 & 0.85 & 0.88 & 0.87 & 0.85 & 0.81 \\
\hline Egypt & 0.69 & 0.60 & 0.28 & 0.30 & 0.41 & 0.50 & 0.42 & 0.27 & 0.50 & 0.49 & 0.67 & 0.57 \\
\hline Pakistan & 0.77 & 0.83 & 0.57 & 0.45 & 0.86 & 0.67 & 0.53 & 0.39 & 0.73 & 0.76 & 0.50 & 0.51 \\
\hline \multicolumn{13}{|c|}{ VALUE } \\
\hline China & 0.90 & 0.90 & 0.86 & 0.78 & 0.74 & 0.81 & 0.69 & 0.73 & 0.73 & 0.72 & 0.73 & 0.66 \\
\hline Netherlands & 0.77 & 0.78 & 0.65 & 0.57 & 0.58 & 0.68 & 0.54 & 0.66 & 0.59 & 0.65 & 0.62 & 0.51 \\
\hline USA & 0.88 & 0.90 & 0.85 & 0.82 & 0.80 & 0.87 & 0.80 & 0.86 & 0.83 & 0.84 & 0.84 & 0.79 \\
\hline Egypt & 0.63 & 0.42 & 0.22 & 0.08 & 0.10 & 0.31 & 0.12 & 0.06 & 0.13 & 0.20 & 0.49 & 0.12 \\
\hline Pakistan & 0.69 & 0.81 & 0.51 & 0.29 & 0.76 & 0.67 & 0.43 & 0.39 & 0.69 & 0.69 & 0.28 & 0.04 \\
\hline
\end{tabular}

Source: Author's own Calculations.

\section{Comparative Export performance}

Comparative Export Performance Index is calculated to determine the comparative advantage and competitiveness of India's onion exports in the global market. A perusal of the table 3 represents the CEP index values of selected countries with reference to India. The range of CEP index varies from 1.76 to 16.62 (for quantities) and from 1.08 to 18.75 (for values). Values of all countries are greater than 1, which indicates comparative advantage of all the countries. However, the calculated values are showing the decreasing index in all countries over the years, which indicates the rise of Indian onion export in the world market.

\section{Symmetric Comparative Export Performance (SCEP)}

The perusal of table 4 represents the symmetric form of the CEP index. The value for index is ranging from 0.27 to 0.89 (for quantities) and from 0.04 to 0.90 (for values). The SCEP Index values of the USA and China are much closer to +1 as compared to others in selected years, implying the high comparative export performance of both the countries.

\section{CONCLUSION}

Onion is an important horticultural commodity grown worldwide with an area of 3 million ha and production to the tune of 55 million tonnes. India is the second largest producer of onion in the world. The present study is an attempt to examine the export competitiveness of onion crop with reference to India. Secondary data is employed to accomplish the objectives obtained from various sources for period 2008-2019. Balassa Index is used to analyse export competitiveness. Revealed comparative advantage index indicates that India, 
the Netherlands, and Egypt have a comparative advantage in onion export. However, the USA and China have a high comparative export performance index over the period. Indian onion has highest RCA index values meaning India has a high demand for its onion compared to other nations in international trade. CEP index of all nations has declined over the period with reference to India. Indian onion has a high competitive advantage thus it needs to be scrutinize consistently to retain the promising position in the global market.

\section{REFERENCES}

APEDA. 2021. Agricultural and Processed Food Products Export Development Authority, India. Disponible en https://agriexchange.apeda.gov.in/ (Last accessed on $22^{\text {nd }}$ July, 2021)

Balassa, B. 1965. Trade liberalization and revealed comparative advantage. The Manch Sch., 33(1): 99-123.

Bendre, A.B. and Newaskar, V.R. 2014. The Study of Trends in Exports of Onion from India. Int. J. Dev. Res., 4(8): 1559-1561.

Dalum, B., Laursen, K. and Villumsen, G. 1998. Structural Change in OECD Export Specialisation Patterns: Despecialisation and Stickiness. Int. Rev. Appl. Econ., 12(3): 423-443.
FAO. 2021. Food and Agriculture Organization of the United Nations. Disponible en https://www.fao.org/faostat/en/ (Last accessed on $22^{\text {nd }} J u l y, 2021$ )

Kumar, N.R. and Gummagolmath, K.C. 2021. Domestic and Export Competitiveness of Major Agricultural Commodities in India with special reference to Telangana. 149 p. National Institute of Agricultural Extension Management.

Laursen, K. 2015. Revealed Comparative Advantage and the Alternatives as Measures of International Specialisation. Eurasian Econ. Rev., 5(1): 99-115.

Rao, E.P. and Ankalam, B. 2018. Comparative Export Performance (CEP) and Revealed Comparative Advantage (RCA) of Paddy: with reference to India. J. Emerg. Technol. Innov. Res., 5(2): 306-313.

Shinoj, P. and Mathur, V.C. 2008. Comparative Advantage of India in Agricultural Exports vis-á-vis Asia: A Postreforms Analysis. Agric. Econ. Res. Rev., 21: 60-66.

Varma, P. and Issar, A. 2016. Pricing to Market Behaviour of India's High Value Agri-food Exporters: An Empirical Analysis of Major Destination Markets. Agric. Econ., 47: 129-137.

Widodo, T. 2009. Comparative Advantage: Theory, Empirical Measures and Case Studies. Rev. Econ. Stud., 4: 57-82. 
